\title{
Pengaruh Model Pembelajaran CMP berbantuan Google Classroom terhadap Kemampuan Representasi Matematis Siswa SMP Negeri 227 Jakarta
}

\author{
Hasna Afifah ${ }^{1, \text { a) }}$, Pinta Deniyanti Sampoerno ${ }^{2, \text { b) }}$, Tian Abdul Aziz ${ }^{3, c)}$ \\ ${ }^{123}$ Universitas Negeri Jakarta \\ Email: ${ }^{\text {a)hasnaafifah08@gmail.com, }}, \underline{\text { b) pinta_ds@yahoo.com, }}, \underline{\text { c) }} \underline{\text { ian_aziz@unj.ac.id }}$
}

\begin{abstract}
Abstrak
Penelitian ini bertujuan untuk mengetahui apakah terdapat pengaruh model pembelajaran CMP berbantuan google classroom terhadap kemampuan representasi matematis siswa. Metode penelitian yang digunakan adalah metode quasi experiment. Teknik pengambilan sampel menggunakan teknik cluster random sampling dan simple random sampling. Sampel pada penelitian ini terdiri dari 32 siswa di kelas eksperimen (menggunakan model pembelajaran CMP berbantuan google classroom) dan 31 siswa di kelas kontrol (menggunakan model pembelajaran konvensional). Kedua kelas tersebut telah memenuhi syarat normalitas dan homogenitasnya serta memiliki kesamaan rata-rata. Instrumen yang digunakan adalah hasil tes kemampuan representasi matematis siswa pada pokok bahasan Bangun Ruang Sisi Datar. Tes tersebut sebanyak enam soal yang berbentuk uraian dan telah melalui pengujian validitas dan reliabilitas. Berdasarkan hasil penelitian, data tersebut berasal dari populasi yang berdistribusi normal dan memiliki varians yang homogen. Oleh karena itu, pengujian hipotesis statistik menggunakan uji-t dengan varians yang sama. Berdasarkan hasil pengujian diperoleh nilai $\boldsymbol{t}_{\text {hitung }}=2,079>$ $\boldsymbol{t}_{\text {tabel }}=\mathbf{1 , 6 6 9}$, sehingga tolak $\boldsymbol{H}_{\mathbf{0}}$ dengan taraf signifikansi $\boldsymbol{\alpha}=\mathbf{0 , 0 5}$. Hal tersebut menunjukkan bahwa terdapat pengaruh model CMP berbantuan google classroom terhadap kemampuan representasi matematis siswa di SMP Negeri 227 Jakarta. Berdasarkan perhitungan besar pengaruh diperoleh nilai $d$ $=0,524$ sehingga termasuk dalam kategori Medium yang berarti memiliki pengaruh yang sedang yaitu sebesar $33 \%$.
\end{abstract}

kata kunci: model pembelajaran CMP, google classroom, kemampuan representasi matematis.

\section{PENDAHULUAN}

Komponen yang menjadi benar-benar berarti dalam kehidupan untuk meningkatkan mutu pendidikan salah satunya adalah kualitas sumber daya manusia. Seseorang dapat menghadapi perubahan karena kemampuan pada diri seseorang dapat dikembangkan dari pendidikan. Pendidikan berfungsi guna meningkatkan kemampuan siswa dan membangun karakter siswa. Kualitas sumber daya manusia bisa memperlengkap seseorang melalui kemampuan berpikir logis, kritis, kreatif dan sistematis untuk berkolaborasi, sehingga sumber daya manusia yang bermutu bisa berpengaruh dalam kesuksesan suatu bangsa, serta nilai perilaku seseorang dapat mempertanggungjawabkan kehidupan bangsa. Mata pelajaran yang memegang peranan luar biasa dalam kehidupan yakni salah satunya matematika.

Menurut Romlah (2020) matematika ialah suatu ilmu pengetahuan yang bersifat umum dan pengetahuan dasar yang dapat mengembangkan teknologi yang modern. Oleh karena itu, kemampuan matematika sebagai hal yang mendasar dan harus dikuasai oleh seluruh manusia agar dapat memengaruhi dan mewujudkan teknologi di masa depan. Adapun tujuan dari pembelajaran matematika termuat pada Permendikbud No. 59 Tahun 2014 yang mengartikan bahwa siswa dapat mengkomunikasikan gagasan atau ide, serta dapat merakit data melalui simbol, tabel, diagram, kalimat 
lengkap atau yang lainnya guna lebih menjelaskan suatu masalah. Kemampuan ini termasuk dalam beberapa indikator yang terdapat pada kemampuan representasi matematis.

NCTM menyebutkan tolak ukur kemampuan matematis yakni pemecahan masalah, koneksi, penalaran, komunikasi dan representasi. Menurut Goldin (dalam Hasanah, 2019) representasi ialah unsur yang amat bermanfaat dalam pembelajaran matematika. Representasi mempunyai alasan penting yang mendasar dalam pembelajaran matematika yaitu sebagai berikut:

1. Matematika memakai bahasa simbol.

2. Matematika dapat mengkonseptualisasi dunia nyata.

3. Pemanfaatan matematika yang sangat luas dan struktur menjadi saling berkaitan.

Dari beberapa alasan di atas, maka setiap individu harus dapat merepresentasi dalam mempelajari matematika.

Berdasarkan survei PISA dibidang kemampuan matematika pada tahun 2018 memperlihatkan bahwa hasil skor siswa di Indonesia yaitu 379 dari rata-rata skor OECD 489 dan Indonesia berada pada peringkat 72 . Hasil ini memperlihatkan bahwa Indonesia termasuk dalam 10 besar terbawah dari seluruh negara. Hasil ini menandakan bahwa Indonesia mempunyai masalah dalam pembelajaran matematika. Hutagaol (dalam Sinaga, 2018) menyatakan bahwa penyampaian materi dalam pembelajaran matematika terdapat suatu masalah, yaitu kemampuan representasi siswa kurang berkembang, siswa hanya mengikuti contoh yang diberikan oleh gurunya saja dan tidak mendapat kesempatan untuk menghadirkan representasinya sendiri.

Menurut Hudiono (dalam Sinaga, 2018) menyatakan bahwa terjadinya kelemahan representasi siswa yaitu guru hanya memaparkan tabel, gambar, model ataupun yang lainnya sebagai pelengkap dalam penyampaian materi saja. Ketika siswa diberikan suatu permasalahan oleh guru, siswa hanya mengikuti contoh-contoh yang sudah dipaparkan saja. Ketika diberikan permasalahan yang tidak sama dengan contoh soal yang dipaparkan, beberapa siswa banyak yang belum bisa menyelesaikan permasalahan tersebut. Hal tersebut menunjukkan bahwa adanya permasalahan dalam penyampaian materi dan siswa tidak mendapatkan kesempatan untuk memunculkan representasinya sendiri.

Hasil wawancara dengan guru matematika menurut Sanjaya, Maharani, dan Basir (2018) yakni sebagai berikut:

1. Pada representasi visual, kemampuan siswa dalam memahami gambar dengan tepat masih kurang.

2. Pada representasi simbolik, kemampuan siswa dalam melakukan operasi hitung masih sering salah.

3. Pada representasi verbal, kemampuan siswa dalam mengatasi permasalahan soal dengan langkah-

langkah masih belum tepat dan siswa belum bisa menyimpulkan dengan tepat.

Hasil wawancara diatas disimpulkan bahwa kemampuan siswa masih amat lemah dalam merepresentasikan masalah matematika. Beberapa siswa memiliki caranya sendiri-sendiri guna memecahkan sebuah masalah matematika yang telah diberikan. Selain itu, siswa masih belum terbiasa merepresentasikan bentuk yang diberikan kedalam bentuk lainnya. Rendahnya kemampuan representasi siswa sejalan dengan hasil studi pendahuluan Sulistyowaty, Kesumah, dan Priatna (2019) menyatakan bahwa hasil pekerjaan siswa belum mampu menyampaikan kembali kalimat matematika dalam bentuk gambar, sehingga siswa belum tepat dalam memecahkan permasalahan yang diberikan. Hal ini diduga siswa tersebut belum biasa dan terlatih dalam menggunakan dan mengembangkan kemampuan representasi matematisnya.

Peranan guru menjadi sangat penting dalam memastikan model kegiatan belajar yang cocok guna meningkatkan kemampuan siswa dalam mempresentasikan masalah matematika. Model belajar secara konvensional menjadi kebiasaan dan belum mampu untuk mengembangkan kemampuan merepresentasikan matematika dengan maksimal, karena pembelajaran secara konvensional tersebut lebih condong pada penyampaian teori saja. Model pembelajaran yang menjadi alternatif demi mengembangkan kemampuan merepresentasikan matematika yaitu model pembelajaran CMP.

Menurut Puteri dan Riwayati (2017) pada model pembelajaran CMP, siswa mendapatkan peluang yang sangat luas untuk menemukan dan menciptakan pengetahuannya sendiri dengan cara menyelesaikan permasalahan tersebut secara berpasangan ataupun kelompok dan diakhiri dengan diskusi bersama untuk mendapatkan solusi yang efektif dan pemahaman yang kuat. Hal tersebut membuat siswa terpacu untuk berperan aktif karena bisa bertukar pendapat dengan temannya. Menurut Rohendi dan Dulpaja (2013) model pembelajaran CMP dapat mendorong pemahaman masalah secara 
mendalam dengan mempresentasikan kedalam bentuk grafik, numeric, simbolik, dan verbal, kemudian membahas dan mengevaluasi masalah tersebut.

W. P. Sari, Haji, dan Nirwana (2020) menyatakan bahwa model belajar CMP menerapkan kegiatan belajar dengan tugas-tugas agar siswa lebih aktif dalam pembelajaran dan bertukar pikiran dengan kelompoknya sehingga menghasilkan suatu kesadaran untuk memahami suatu konsep baru. Langkah-langkah model pembelajaran CMP yakni launching problem, exploring dan summarizing. Langkah-langkah ini bisa membantu siswa dalam melatih kemampuan pemahamannya, sehingga siswa dapat mengatasi suatu permasalahan.

Penyebaran corona virus disease (covid-19) mengakibatkan proses pembelajaran diterapkan dari rumah sehingga diperlukan kemampuan guru dalam menerapkan media pembelajaran online dan model belajar yang cocok. Menurut Andriani (2021) model belajar yang cocok yakni model pembelajaran CMP, karena model pembelajaran tersebut bisa diimplementasikan secara online, serta dengan model CMP bisa dikaitkan dengan kehidupan sehari-hari agar meningkatkan pembelajaran yang bermakna.

Penerapan media pembelajaran online yaitu melalui beberapa aplikasi, seperti whatsapp group, video youtube, zoom meeting, edmodo, dan google classroom. Ketersediaan layanan internet menjadi tantangan tersendiri dalam pembelajaran online. Gangguan eksternal dirumah juga menjadi tantangan dalam belajar online. Siswa menganggap sulit untuk melaksanakan pembelajaran jarak jauh karena tidak semua siswa menggunakan layanan WiFi. Menurut Firman dan Rahayu (2020) pembelajaran yang dilakukan dalam bentuk video banyak menghabiskan kuota, sementara bentuk diskusi online melalui aplikasi pesan tidak terlalu menghabiskan banyak kuota.

Menurut Kurniawan (2016) penerapan aplikasi google classroom dapat memberikan pengalaman belajar yang sangat luas secara aktif dalam kegiatan diskusi. Selain itu, google classroom dapat memperkaya materi, mengembangkan ide dan terbiasa menyelesaikan kuis. Hal tersebut terlihat dari keikutsertaan dalam diskusi dan kuis. Google classroom mempermudah siswa dan guru untuk berinteraksi dengan baik. Google classroom menjadi jembatan bagi guru agar merampingkan proses kegiatan belajar mengajar secara online.

Berlandaskan uraian di atas, maka dilakukan penelitian terkait kemampuan merepresentasikan matematika guna membantu siswa, sehingga siswa tersebut mampu menyelesaikan permasalahan dengan merepresentasikan masalah tersebut. Proses pembelajaran didampingi oleh guru yang bersangkutan. Kemudian dalam penelitian akan membuat lintasan belajar yakni dengan menerapkan model pembelajaran CMP dan dengan berbantuan google classroom.

\section{METODE}

Metode yang diterapkan ialah metode quasi experiment dengan desain penelitian ini ialah PostTest Only Control Group Design. Populasi target penelitian ini ialah seluruh siswa SMP Negeri 227 Jakarta. Setelah itu diaplikasikan teknik Cluster random sampling pada kelas VII, VIII, dan IX guna mendapatkan populasi terjangkau. Kelas yang terpilih menjadi populasi terjangkau yaitu kelas VIII. Apabila dibatasi oleh guru yang mengajar kelas yang sama maka terdapat kelas VIII-A sampai VIII-D. Sebelum diberikan perlakuan, dilakukan terlebih dahulu pengujian kesamaan rata-rata dengan uji anava satu arah dari hasil PAS matematika siswa. Prasyarat uji anava satu arah yaitu dilakukan dahulu uji normalitas memakai uji Liliefors dan uji homogenitas memakai uji Bartlett. Pengujian tersebut dilakukan guna melihat kondisi awal kelas bahwa kelas tersebut berdistribusi normal, homogen, dan mempunyai kesamaan rata-rata. Jika semua uji telah terpenuhi, maka dilakukan pengambilan sampel yakni menerapkan teknik Simple random sampling guna menetapkan kelas yang menjadi sampel penelitian. Penelitian ini terpilih dua kelas yakni satu kelas eksperimen yang diberikan perlakuan, yaitu menerapkan model pembelajaran CMP berbantuan google classroom dan satu kelas kontrol yang tidak diberikan perlakuan, yaitu menerapkan model pembelajaran secara konvensional.

Instrumen penelitian yang digunakan ialah instrumen tes kemampuan representasi matematis pada materi Bangun Ruang Sisi Datar. Tes tersebut berjumlah enam soal uraian yang telah diuji validitas isi, konstruk, empiris dan reliabilitasnya. Hasil pengujian validatas empiris dapat dilihat pada Tabel 1 sebagai berikut: 
TABEL 1. Hasil Pengujian Validitas Empiris Instrumen Tes

\begin{tabular}{lcccll}
\hline Butir Soal & $\boldsymbol{r}_{\boldsymbol{x y}}$ & $\boldsymbol{r}_{\text {tabel }}$ & Keterangan & Kesimpulan & Kategori \\
\hline 1 & 0.778 & 0.349 & $r_{x y}>r_{\text {tabel }}$ & Valid & Tinggi \\
\hline 2 & 0.478 & 0.349 & $r_{x y}>r_{\text {tabel }}$ & Valid & Cukup \\
\hline 3 & 0.672 & 0.349 & $r_{x y}>r_{\text {tabel }}$ & Valid & Tinggi \\
\hline 4 & 0.561 & 0.349 & $r_{x y}>r_{\text {tabel }}$ & Valid & Cukup \\
\hline 5 & 0.442 & 0.349 & $r_{x y}>r_{\text {tabel }}$ & Valid & Cukup \\
\hline 6 & 0.547 & 0.349 & $r_{x y}>r_{\text {tabel }}$ & Valid & Cukup \\
\hline
\end{tabular}

Adapun hasil perhitungan reliabilitas instrumen post-test, didapatkan koefisien reliabilitas instrumen yaitu 0,612. Hal ini memperlihatkan bahwa reliabilitas instrumen post-test tergolong tingkat tinggi. Teknik analisis data yang digunakan pada penelitian ini adalah uji prasyarat analisis data sebelum perlakuan yang terdiri dari uji normalitas menggunakan uji Liliefors, uji homogenitas menggunakan uji Bartlett dan kesamaan rata-rata menggunakan uji ANAVA satu arah. Selanjutnya dilakukan uji prasyarat analisis data setelah perlakuan terdiri dari uji normalitas menggunakan uji Liliefors, uji homogenitas menggunakan uji Fisher dan uji analisis data menggunakan uji-t dengan varians yang sama. Kemudian dilanjutkan Uji Cohen untuk mengetahui besar pengaruh model pembelajaran CMP berbantuan google classroom terhadap kemampuan representasi matematis siswa SMP Negeri 227 Jakarta.

\section{HASIL DAN PEMBAHASAN}

\section{Hasil}

Berdasarkan penelitian, peneliti melakukan pengujian pada teknik analisis data. Hasil pengujian tersebut sebagai berikut:

Hasil uji normalitas sebelum perlakuan disajikan dalam tabel 2 sebagai berikut:

TABEL 2. Hasil Uji Normalitas Sebelum Perlakuan

\begin{tabular}{llllll}
\hline Kelas & $\mathbf{N}$ & $\boldsymbol{L}_{\text {hitung }}$ & $\boldsymbol{L}_{\text {tabel }}$ & Keterangan & Keputusan \\
\hline VIII-A & 37 & 0,138 & 0,146 & $L_{\text {hitung }}<L_{\text {tabel }}$ & Terima $H_{0}$ \\
\hline VIII-B & 36 & 0,116 & 0,148 & $L_{\text {hitung }}<L_{\text {tabel }}$ & Terima $H_{0}$ \\
\hline VIII-C & 36 & 0,088 & 0,148 & $L_{\text {hitung }}<L_{\text {tabel }}$ & Terima $H_{0}$ \\
\hline VIII-D & 34 & 0,140 & 0,152 & $L_{\text {hitung }}<L_{\text {tabel }}$ & Terima $H_{0}$ \\
\hline
\end{tabular}

Berdasarkan tabel di atas, menunjukkan bahwa keempat kelas tersebut berasal dari populasi yang berdistribusi normal.

Hasil uji homogenitas sebelum perlakuan diperoleh $X^{2}{ }_{\text {hitung }}=7,665$ dan $X^{2}$ tabel $=7,815$. Hasil perhitungan tersebut menunjukkan bahwa $X^{2}{ }_{\text {hitung }}<X^{2}$ tabel sehingga dapat disimpulkan bahwa kelas VIII-A, VIII-B, VIII-C dan VIII-D berasal dari populasi yang homogen.

Hasil uji kesamaan rata-rata sebelum perlakuan disajikan dalam tabel 3 sebagai berikut:

TABEL 3. Hasil Uji Kesamaan Rata-rata Sebelum Perlakuan

\begin{tabular}{lllllll}
\hline SV & DK & JK & MK & $\boldsymbol{F}_{\text {hitung }}$ & $\boldsymbol{F}_{\text {tabel }}$ & Keputusan \\
\hline Total & 142 & 35607,8 & & & & \\
\cline { 1 - 4 } Ant & 3 & 344,903 & 114,968 & 0,453 & 2,670 & Terima $H_{0}$ \\
\cline { 1 - 4 } Dal & 139 & 35262,9 & 253,69 & & & \\
\hline
\end{tabular}


Berdasarkan tabel di atas, menunjukkan bahwa $F_{\text {hitung }}<F_{\text {tabel }}$ sehingga dapat disimpulkan bahwa terima $H_{0}$ atau memiliki rata-rata yang sama.

Hasil uji normalitas setelah perlakuan disajikan dalam tabel 4 sebagai berikut:

TABEL 4. Hasil Uji Normalitas Setelah Perlakuan

\begin{tabular}{lcccc}
\hline Kelas & $\boldsymbol{L}_{\text {hitung }}$ & $\boldsymbol{L}_{\text {tabel }}$ & Keterangan & Keputusan \\
\hline $\begin{array}{l}\text { Eksperimen } \\
\text { (VIII-B) }\end{array}$ & 0,116 & 0,157 & $L_{\text {hitung }}<L_{\text {tabel }}$ & Terima $H_{0}$ \\
\hline $\begin{array}{l}\text { Kontrol } \\
\text { (VIII-D) }\end{array}$ & 0,139 & 0,159 & $L_{\text {hitung }}<L_{\text {tabel }}$ & Terima $H_{0}$ \\
\hline
\end{tabular}

Berdasarkan tabel di atas, menunjukkan bahwa hasil tes kemampuan representasi matematis siswa kelas eksperimen (kelas VIII-B) dan kelas kontrol (kelas VIII-D) pada pokok bahasan bangun ruang sisi datar tersebut berdistribusi normal.

Hasil uji homogenitas setelah perlakuan diperoleh $F_{\text {hitung }}=1,370$, sedangkan $F_{(0,025)(30,31)}=$ 2,057 . Hal tersebut menunjukkan bahwa $F_{\text {hitung }}<F_{(0,025)(30,31)}$, sehingga dapat disimpulkan terima $H_{0}$ atau kedua kelas tersebut homogen.

Hasil uji hipotesis statistik disajikan dalam tabel 5 sebagai berikut:

\begin{tabular}{cccl}
\multicolumn{4}{c}{ TABEL 5. Hasil Uji Hipotesis Statistik } \\
\hline $\boldsymbol{t}_{\text {hitung }}$ & $\boldsymbol{t}_{\text {tabel }}$ & Keterangan & Keputusan \\
\hline 2,079 & 1,669 & $t_{\text {hitung }}>t_{\text {tabel }}$ & Tolak $H_{0}$ \\
\hline
\end{tabular}

Berdasarkan tabel di atas menunjukkan bahwa nilai $t_{\text {hitung }}$ yaitu sebesar 2,079 dan nilai $t_{\text {tabel }}=$ $t_{(1-\alpha)(d k)}=t_{(1-0,05)(61)}=1,669$. Hal tersebut menunjukkan bahwa $t_{\text {hitung }} \geq t_{1-\alpha}$ yang keputusannya adalah tolak $H_{0}$ dan dapat dibuat kesimpulannya yakni rata-rata nilai kemampuan siswa dalam merepresentasikan matematika dengan model pembelajaran CMP berbantuan google classroom lebih tinggi dari rata-rata nilai kemampuan siswa dalam merepresentasikan matematika dengan model pembelajaran secara konvensional.

Hasil perhitungan dan interpretasi besar pengaruh dapat disajikan dalam tabel 6 sebagai berikut:

TABEL 6. Hasil Perhitungan Besar Pengaruh

\begin{tabular}{lll}
\hline ES & Percent of Nonoverlap & Cohen's Standard \\
\hline 0,524 & $33 \%$ & Medium \\
\hline
\end{tabular}

Berdasarkan tabel di atas menunjukkan bahwa nilai $d=0,524$ sehingga termasuk dalam kategori Medium yang berarti memiliki pengaruh yang sedang yaitu sebesar 33\%. Dengan demikian, dapat disimpulkan bahwa model pembelajaran CMP berbantuan google classroom memiliki pengaruh yang sedang terhadap kemampuan representasi matematis siswa SMP Negeri 227 Jakarta yaitu sebesar 33\%.

\section{Pembahasan}

Berdasarkan hasil perhitungan pengujian hipotesis statistik diperoleh bahwa terdapat pengaruh model pembelajaran Connected Mathematics Project (CMP) berbantuan google classroom terhadap kemampuan representasi matematis siswa. Rata-rata hasil tes kemampuan representasi matematis siswa kelas eksperimen yaitu 85,096, sedangkan rata-rata hasil tes kemampuan representasi matematis siswa kelas kontrol yaitu 80,811. Perbedaan rata-rata hasil tes kemampuan representasi matematis siswa antara kelas eksperimen dan kelas kontrol terjadi karena adanya perbedaan penerapan model pembelajaran.

Pada pembelajaran yang sudah dirancang mempunyai perbedaan pada kelas eksperimen dan kelas kontrol, yaitu peran guru dan siswa. Pada kelas eksperimen guru mempunyai peran sebagai fasilitator, guru hanya memandu jalannya pembelajaran dan mengevaluasi materi yang dipelajari. Hal 
tersebut membuat siswa aktif dalam pembelajaran yaitu dengan berdiskusi dengan teman serta berdiskusi dengan guru jika masih ada yang kurang jelas. Sedangkan pada kelas kontrol, siswa cenderung kurang aktif dan guru memegang peran besar dari awal sampai akhir pembelajaran sehingga pembelajaran hanya berlangsung satu arah. Perbedaan tersebut berpengaruh pada kemampuan representasi matematis siswa, sehingga kemampuan representasi matematis siswa kelas eksperimen lebih baik daripada kemampuan representasi matematis kelas kontrol.

Besar pengaruh model pembelajaran CMP berbantuan google classroom terhadap kemampuan representasi matematis siswa sebesar 33\%. Pengaruh tersebut termasuk kategori pengaruh sedang berdasarkan tabel cohen's effect size. Besar pengaruh model pembelajaran CMP berbantuan google classroom tidak berada pada presentase maksimal, karena pada saat pembelajaran berlangsung terdapat beberapa kendala. Adapun kendala pada kelas eksperimen dalam penelitian ini yaitu sebagai berikut:

1. Siswa kesulitan dalam mengerjakan LKPD karena pada pembelajaran biasanya siswa hanya mendengarkan apa yang disampaikan oleh guru.

2. Waktu yang tersedia dalam PJJ ini tidak cukup untuk melaksanakan seluruh rangkaian pembelajaran dengan baik. Pada saat diskusi kelompok waktu yang dilaksanakan sangat singkat, sehingga LKPD sulit di selesaikan dengan baik.

3. Pembagian kelompok dalam pembelajaran berlangsung tidak bisa terbagi secara heterogen, sehingga terdapat beberapa kelompok yang belum antusias dalam berdiskusi.

Berdasarkan kendala yang ditemukan dikelas eksperimen, maka wajar saja pengaruh CMP hanya berpengaruh sedang. Walaupun hanya berpengaruh sedang, kegiatan model pembelajaran CMP berbantuan google classroom terbukti meningkatkan kemampuan representasi matematis siswa. Penelitian ini menguatkan pendapat menurut Sartika dan Rifai (2018) yang menyatakan bahwa model pembelajaran CMP mengikuti teori konstruktivisme yang menyatakan bahwa guru hanya mendorong siswa untuk menemukan caranya sendiri dalam menyelesaikan masalah.

Penelitian ini mempunyai hasil penelitian yang serupa dengan hasil penelitian sebelumnya yaitu penelitian menurut Widarti dkk (2014). Hasil penelitian tersebut menyatakan bahwa penelitian berbasis masalah berpengaruh untuk meningkatkan kemampuan representasi matematis siswa. Adapun hasil penelitian ini juga relevan dengan hasil penelitian sebelumnya yaitu menurut W.P. Sari dkk (2020) yang menyatakan rata-rata kelas yang diajarkan dengan model pembelajran CMP lebih tinggi daripada kelas yang diajarkan dengan model pembelajaran konvensional. Selain itu, hasil penelitian ini juga relevan dengan hasil penelitian sebelumnya yaitu menurut Mulyani dkk (2017) yang menyatakan bahwa menerapkan model pembelajaran CMP dapat meningkatkan hasil belajar siswa dalam pembelajaran.

\section{PENUTUP}

\section{Kesimpulan}

Berdasarkan hasil pengujian hipotesis statistik, diperoleh $t_{\text {hitung }}=2,079$ dan $t_{\text {tabel }}=1,669$ dengan taraf signifikansi $\propto=0,05$. Hal tersebut menunjukkan bahwa model pembelajaran Connected Mathematics Project (CMP) berbantuan google classroom memberikan pengaruh terhadap kemampuan representasi matematis siswa kelas VIII SMP Negeri 227 Jakarta pada pokok bahasan bangun ruang sisi datar. Adapun berdasarkan perhitungan dapat disimpulkan bahwa besar pengaruh model pembelajaran Connected Mathematics Project (CMP) berbantuan google classroom terhadap kemampuan representasi matematis siswa sebesar 33\% dan termasuk kategori sedang.

Berdasarkan pengamatan selama penelitian, terdapat beberapa saran yaitu merancang waktu dengan tepat, mengkaji model pembelajaran CMP berbantuan google classroom dalam meningkatkan kemampuan matematis siswa lainnya dan melakukan perbaikan-perbaikan berdasarkan penelitian yang sudah dilakukan.

\section{REFERENSI}

Andriani, D. (2021). "Understanding the Concept of Geometry Through the Connected Mathematics Project Learning by Using Online Media and Local Culture." Proceedings of the International 
Conference on Educational Sciences and Teacher Profession (ICETeP 2020), 532(532), 124-128.

Firman, F., \& Rahayu, S. (2020). "Pembelajaran Online di Tengah Pandemi Covid-19." Indonesian Journal of Educational Science (IJES), 2(2), 81-89.

Hasanah, N. (2019). "Kemampuan Representasi Matematis Berdasarkan Self-Concept Siswa dengan Pembelajaran Learning Cycle 7E pada Materi Garis Kelas VII Smp Negeri 1 Dau Malang." JPM : Jurnal Pendidikan Matematika, 4(2), 102.

Mulyani, A., Hartanto, H., \& Zamzaili, Z. (2017). "Pengaruh Model Pembelajaran Connected Mathematics Project terhadap Kemampuan Pemahaman Konsep dan Penalaran Matematis di Madrasah Aliyah." Jurnal Pendidikan Matematika Raflesia, 2(1), 118-127.

Puteri, W. J., \& Riwayati, S. (2017). "Kemampuan Koneksi Matematis Siswa pada Model Pembelajaran Conneted Mathematics Project (CMP)." Jurnal Pendidikan Matematika Dan Matematika, 3(2), 161-168.

Rohendi, D., \& Dulpaja, J. (2013). "Connected Mathematics Project (CMP) Model Based on Presentation Media to the Mathematical Connection Ability of Junior High School Student." Journal of Education and Practice, 4(4), 17-22.

Romlah. (2020). "Penerapan Model Round Club dalam Meningkatkan Kemampuan Memahami Bilangan Berpangkat dan Bentuk Akar Pelajaran Matematika Siswa Kelas IX.4 SMP Negeri 43 Palembang." Jurnal Sekolah, 5(1), 104-111.

Sanjaya, I. I., Maharani, H. R., \& Basir, M. A. (2018). "Kemampuan Representasi Matematis Siswa Pada Materi Lingkaran berdasar Gaya Belajar Honey Mumfrod." Penellitian Didaktik Matematika, 2(2), 60-72.

Sari, W. P., Haji, S., \& Nirwana. (2020). "Pengaruh Model Pembelajaran Connected Mathematics Project (CMP) terhadap Kemampuan Pemahaman Konsep Matematika." Jurnal Pendidikan Matematika Raflesia, 05(01), 103-111.

Sartika, N. S., \& Rifai, R. (2018). "Penerapan Model Connected Mathematic Project untuk Meningkatan Kemampuan Berpikir Kreatif Matematis Siswa Madrasah Aliyah." Journal of Mathematics Learning, 1(2), 10-17.

Sinaga, C. T. Y. (2018). "Pengembangan Soal Model PISA dan LKPD Konten Shape and Space dengan Pendekatan RME untuk Meningkatkan Kemampuan Representasi Matematis Siswa di SMA Negeri 1 Dolok Batu Nanggar." IEEE Communications Surveys and Tutorials, 15(4), 2046-2069.

Sulistyowaty, R. K., Kesumah, Y. S., \& Priatna, B. A. (2019). "Peningkatan Kemampuan Representasi Matematis melalui Pembelajaran Collaborative Problem Solving." Jurnal Pendidikan Matematika, 13(2), 153-162.

Widarti, S., Yunarti, T., \& Asnawati, R. (2014). "Penerapan Model PBL untuk Meningkatkan Kemampuan Representasi Matematis Siswa." Jurnal Pendidikan Matematika Unila, 2(4).

Widiyanto, M. A. (2013). Statistika Terapan. Jakarta: PT Elex Media Komputindo. 